\title{
РОЛЬ ЗЕМНОВОДНИХ І ПЛАЗУНІВ У СТВОРЕННІ ЕКОЛОГІЧНОГО БУФЕРУ ПРОТИ ТЕХНОГЕННОГО ЗАБРУДНЕННЯ
}

Показано, що рийна активність часничниці звичайної Pelobates fuscus (Laurenti, 1768) в умовах забруднення грунтів важкими металами здатна позитивно впливати на вміст металів у грунті. Трофометаболічна активність (виділення екскрецій) земноводних (P. fuscus) і плазунів (ящірки прудкої, Lacerta agilis Linnaeus, 1758) зменшус вміст важких металів у грунті.

\author{
V. L. Bulakhov, V. Y. Gasso \\ Oles' Gonchar Dnipropetrovsk National University
}

\section{ROLE OF AMPHIBIANS AND REPTILES IN CREATION OF AN ECOLOGICAL BUFFER AGAINST TECHNOGENIC POLLUTION}

It has shown that fossorial activity of common spadefoot Pelobates fuscus (Laurenti, 1768) under conditions of heavy metals pollution of soils is able to reduce the level of the metals in soil. Tropho-metabolic activity (faeces excretion) of amphibians (P. fuscus) and reptiles (sand lizard Lacerta agilis Linnaeus, 1758) decreases the content of heavy metals in soils.

\section{Вступ}

Нині значний інтерес викликає вивчення ролі тварин, які своєю середовищетвірною активністю сприяють утворенню екологічних механізмів у спонтанних процесах самоочищення екосистем від різних техногенних забруднювачів, серед яких в умовах промислових регіонів пріоритетне місце займають важкі метали. Встановлено, що важливу роль у зв'язуванні важких металів відіграють хімічні процеси, які володіють поліфункціональними властивостями та хелатувальною здатністю органічних речовин $[12 ; 14 ; 16-18]$. Органічні речовини знижують їх біодоступність для рослин, переводячи у нерозчинний стан $[7 ; 8 ; 13 ; 15]$. Дослідження, проведені з іншими тваринами (ссавцями), які своєю активністю сприяють зростанню вмісту органічних речовин, показують їх значну роль у блокуванні важких металів $[1 ; 2 ; 4-6 ; 9 ; 10]$. У зв’язку з цим важливим $\epsilon$ визначення ролі інших тварин (у тому числі земноводних і плазунів) у створенні механізмів самоочищення екосистем і блоків екосистем від техногенного забруднення, яке з кожним роком зростає.

\section{Матеріал і методи досліджень}

Матеріал збирали протягом 1996-2005 років. Головним методичним засобом дослідження ролі земноводних і плазунів у створенні екологічного буферу проти техногенного забруднення був обраний порівняльний метод (на основі експериментальних робіт). Виділено контрольні (з ізоляцією від проникнення земноводних і плазунів) та експериментальні ділянки грунту з розміщенням метаболітів або пориїв вказаних тва- 
рин. Ділянки розміщували в ідентичних природних умовах липо-ясеневих дібров із внесенням однакової концентрації одного 3 пріоритетних забруднювачів - кадмію або свинцю. На вказаних ділянках через 3 та 6 місяців відбирали проби грунту та визначали концентрацію валової та рухомої форми металів. Визначення концентрації різних форм металів проводили з використанням атомно-абсорбційної спектрофотометрії на спектрофотометрі AAS-30 (Carl Zeiss, Німеччина) [11]. Ефективність впливу земноводних і плазунів визначали через зниження концентрації металів (у відсотках до контролю).

\section{Результати та їх обговорення}

Особливу роль у процесі самоочищення грунтів відіграють гумус та інтенсивність гумусоутворення, які є реагентами нейтралізації важких металів. Досліджено роль земноводних у процесах формування фізичних властивостей грунтів, інтенсивність яких у різних біогеоценозах під дією трофометаболітів значно зростає [3]. Значну роль у зниженні забруднення грунтів відіграє рийна активність, особливо ті види пориїв, що утворюють вертикальні пронизуючі коридори, як наприклад, часникова жаба, де значно підвищується водопроникність (в 1,3-1,6 раза). Зі збільшенням водопроникності зростає промивна здатність грунту і міграція важких металів у глибокі, менше доступні для автотрофів шари грунту.

Проведені експериментальні роботи (табл.) показали, що в місцях пориїв земноводних валовий вміст кадмію порівняно з контролем знижується на 9,9-16,7 \%, свинцю - на 6,9-15,4 \%. Причому у середньозабруднених грунтах цей вплив ефективніший. При незначному забрудненні вміст валової форми кадмію вже через три місяці знижується на 14,4 \%, свинцю - на 19,4 \%. При посиленні забруднення грунту вдвічі (середня забрудненість) - відповідно на 18,8 та 19,7 \%. Через шість місяців ці процеси уповільнюються - відбувається зниження вмісту металів на 11,6 та 6,8, 16,7 та 13,5 \% відповідно. При сильному забрудненні ефективність дії понижується. Зменшення вмісту валової форми металів у пориях відбувається в основному за рахунок міграції металів у глибші шари грунту. У той же час у цих же місцях спостерігається ефективніше зменшення вмісту рухомих форм за рахунок переведення їх у нерухомі. Вміст рухомих форм кадмію у пориях при різних рівнях забруднення протягом трьох місяців зменшується на 19,3-23,6\%, протягом шести місяців - на 19,4-31,2 \%; свинцю - на 14,525,2 \% і 12,6-24,1 \% відповідно.

Вплив екскрецій часничниці на валовий вміст металів незначний. У тримісячний термін дії екскрецій при різних рівнях забруднення вміст валової форми кадмію знижується на 2,1-5,2 \%, свинцю - на 2,4-5,2\%. Ефективність впливу екскрецій на перетворення рухомих форм металів у нерухомі більша. Вміст рухомих форм кадмію за три місяці знижується на 33,6-69,8 \%, за шість місяців - на 17,9-27,4 \%. Вміст рухомих форм свинцю зменшується на 24,9-70,4 \% і 16,3-29,5 \% відповідно. Очевидно, що найактивніше екскреції земноводних діють на початку свого впливу, коли вони свіжіші.

У плазунів досліджувався вплив лише трофометаболічної активності у зв'язку зі значно меншим обсягом рийної активності. Як і у земноводних, вплив екскрецій на валовий вміст металів порівняно з їх дією на вміст рухомих форм менший. Ефективність їх зниження у перші три місяці коливається в межах 1,7-3,3 \% для кадмію та 2,3$4,5 \%$ для свинцю. У той же час ефективність впливу екскрецій на вміст рухомих форм металів на порядок вища. Вміст рухомої форми кадмію під тримісячною дією екскрецій знижується при різних рівнях забруднення на 19,8-45,2 \%, свинцю - на 17,7-31,1\%. 
Вплив середовищетвірної активності часничниці та прудкої ящірки на блокування важких металів у забруднених грунтах*

\begin{tabular}{|c|c|c|c|c|c|c|c|c|c|c|}
\hline \multirow{4}{*}{ Вид } & \multirow{4}{*}{ 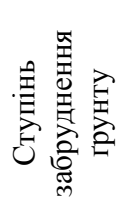 } & \multirow{4}{*}{ 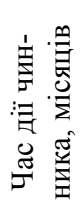 } & \multicolumn{8}{|c|}{ Ефективність зниження вмісту металів, \% від контролю } \\
\hline & & & \multicolumn{4}{|c|}{ кадмій } & \multicolumn{4}{|c|}{ свинець } \\
\hline & & & \multicolumn{2}{|c|}{ у пориях } & \multicolumn{2}{|c|}{$\begin{array}{c}\text { під } \\
\text { екскрементами }\end{array}$} & \multicolumn{2}{|c|}{ у пориях } & \multicolumn{2}{|c|}{$\begin{array}{c}\text { під } \\
\text { екскрементами }\end{array}$} \\
\hline & & & $B$ & $P$ & $B$ & $P$ & $B$ & $P$ & $B$ & $P$ \\
\hline \multirow{6}{*}{ 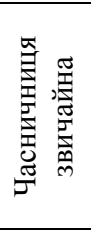 } & \multirow{2}{*}{$I$} & 3 & 14,4 & 19,3 & 5,2 & 33,6 & 19,4 & 22,8 & 4,1 & 24,9 \\
\hline & & 6 & 11,6 & 27,1 & 1,6 & 17,9 & 6,8 & 24,1 & 2,4 & 16,3 \\
\hline & \multirow{2}{*}{ II } & 3 & 18,8 & 23,6 & 4,7 & 36,3 & 19,7 & 25,2 & 5,2 & 31,8 \\
\hline & & 6 & 16,7 & 31,2 & 2,2 & 27,4 & 13,5 & 18,1 & 3,1 & 29,5 \\
\hline & \multirow{2}{*}{ III } & 3 & 12,8 & 21,8 & 2,1 & 69,8 & 8,7 & 14,5 & 2,4 & 70,4 \\
\hline & & 6 & 9,9 & 19,4 & 1,4 & 18,4 & 6,9 & 12,6 & 1,6 & 23,1 \\
\hline \multirow{6}{*}{ 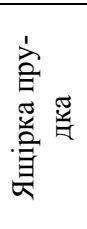 } & \multirow{2}{*}{$I$} & 3 & - & - & 3,3 & 19,8 & - & - & 3,7 & 17,7 \\
\hline & & 6 & - & - & 1,4 & 16,6 & - & - & 1,8 & 15,4 \\
\hline & \multirow{2}{*}{ II } & 3 & - & - & 3,9 & 21,1 & - & - & 4,5 & 18,4 \\
\hline & & 6 & - & - & 1,9 & 23,1 & - & - & 2,5 & 14,3 \\
\hline & \multirow{2}{*}{ III } & 3 & - & - & 1,7 & 45,2 & - & - & 2,3 & 31,1 \\
\hline & & 6 & - & - & 1,2 & 13,4 & - & - & 1,6 & 12,2 \\
\hline
\end{tabular}

Примітки: * - експериментальні дослідження в липо-ясеневій діброві (Присамарський міжнародний біосферний стаціонар ім. О. Л. Бельгарда); за контроль приймали дані без впливу тварин; $B$ - валовий вміст металів, $P$ - рухома форма металів; $I$ - слабкозабруднені грунти, 1,5-2,5 ГДК; $I I$ - середньозабруднені грунти, 3-4 ГДК; III - сильнозабруднені грунти, 7-8 ГДК.

Після піврічної дії ця ефективність дещо знижується, але залишається доволі високою - 13,1-23,1 \% і 12,2-15,4 \% відповідно. У цілому, вплив екскрецій плазунів на вміст різних форм металів у грунті менший, ніж екскрецій земноводних.

Таким чином, різні форми середовищетвірної активності виступають як певні біотичні чинники при блокуванні потенційної шкідливої дії важких металів у едафотопі наземних біогеоценозів.

\section{Висновки}

Середовищетвірна роль земноводних і плазунів виступає дієвим екологічним чинником у створенні природного буферу проти техногенного забруднення екосистем. Ефективність впливу тварин на зниження ступеня забруднення екосистем залежить від ix кількісного складу. Значний ефективний вплив на зниження забруднення в умовах заплавних дібров здійснює часничниця звичайна.

Головні механізми дії рийної та метаболічної середовищетвірної активності земноводних і плазунів - збагачення грунту гумусом та іншими органічними речовинами, створення умов для зростання водопроникності грунтів. Важкі метали з одного боку вступають у складні хімічні взаємодії з органічними речовинами, утворюючи нерухомі металорганічні сполуки, а з іншого (за рахунок збільшення фільтраційних властивостей грунту) - метали мігрують у глибинні горизонти, недосяжні для автотрофів. Виявлені особливості впливу земноводних і плазунів щодо зниження забруднення наземних екосистем можуть відігрівати важливу роль у розробці заходів з оптимізації довкілля в індустріальних країнах світу. 


\section{Бібліографічні посилання}

1. Булахов В. Л. Біорізноманіття як фактор екологічно стійких екосистем в умовах посиленого антропогенного тиску // Збереження біорізноманітності в Україні. - К.: Егем, 1997. C. $20-21$.

2. Булахов В. Л. Функціональна роль тварин як біогеоценотична основа збереження довкілля в індустріальному регіоні / В. Л. Булахов, О. Є. Пахомов, О. А. Рева // Екологічні проблеми довкілля та шляхи їх вирішення: IX Каришенські читання. - Полтава, 2002. - С. 43-44.

3. Булахов В. Л. Роющие земноводные как естественные экологические факторы формирования физических свойств почв в лесных биогеоценозах / В. Л. Булахов, Н. Л. Губанова // Экология и биология почв. Матер. Междунар. научн. конф. - Ростов-на-Дону, 2005. - С. 73-74.

4. Булахов В. Л. Біологічне різноманіття України. Дніпропетровська область. Ссавці (Mammalia) / В. Л. Булахов, О. Є. Пахомов. - Д.: ДНУ, 2006. - 356 с.

5. Булахов В. Л. Зоогенні механізми утворення захисного блоку екосистем в умовах антропогенного тиску антропогенних чинників в індустріальних регіонах / В. Л. Булахов, О. Є.Пахомов, О. А. Рева // Тези доп. І Всеукр. з’їду екологів. - Вінниця: Універсум, 2006. - C. 152.

6. Вплив середовищетвірної ролі ссавців на утворення механізму самоочищення грунтів від забруднення та перспективи їх використання / В. Л. Булахов, О. Є. Пахомов, О. В. Михєєв, О. А. Рева // Екологічна токсикологія на порозі ХХІ сторіччя. - Київ, 1997. - Вип. 1. - С. 27-29.

7. Евдокимова Т. А. Влияние удобрений на содержание тяжелых металлов в почве / T. А. Евдокимова, Н. П. Маркова // Миграция загрязненных веществ в почве: Тр. IV Всесоюзн. совещ. - Л., 1985. - С. 191-198.

8. Обухов А. И. Устойчивость черноземов к загрязнению тяжелыми металлами // Проблемы охраны, рационального использования и рекультивации черноземов. - М., 1989. - С. 33-42.

9. Пахомов А. Е. Биогеоценотическая роль млекопитающих в почвообразовательных процессах степных лесов Украины. - Д.: ДНУ, 1998. - Т. 1, 2. - 232 с., 228 с.

10. Средообразующая деятельность животных как научно-практическая форма в системе мер по оптимизации окружающей среды / В. Л. Булахов, А. Е. Пахомов, А. А. Рева, Е. А. Лукацкая // Франція та Україна: науково-практичний досвід у контексті діалогу національних культур. - Д., 1998. - Ч. 3. - С. 6-7.

11. Хавезов И. Атомно-абсорбционный анализ / И. Хавезов, Д. Цалев. - Л.: Химия, 1983. - 144 с.

12. Химическая буферность почв / Т. А. Соколова, Г. В. Мотузова, Я. С. Малинина, Г. Д. Обуховская. - М.: МГУ, 1996. - 106 с.

13. Andersson A. Influence of organic fertilizers on the solubility and availability to plants of heavy metals in soils // Grundforbattring. - 1975-1976. - N 4. - P. 159-164.

14. Bollag J.-M. Biological and chemical interaction of pesticides with soil organic matter / J.-M. Bollag, C. J. Myers, R. D. Minard // IV Int. Workshop Chem. Biol. and Ecotoxicol. Behav. Pesticides soil environ. - Rome: Sci. Total Environ., 1992. - P. 205-217.

15. Christensen T. H. The effect of dissolved organic carbon on the mobility of cadmium, nickel and zinc in groundwater / T. H. Christensen, I. B. Christensen // Contaminated soils. III Int. Confer. Biogeochemistry Trance Elements. Abstr. Theme B. Impacts and Pathways of Exposure. - Paris, 1995. - P. 275.

16. Franco U. Eflus verschidener organi scher Diinger aut dii Minaralisierungs dynamik in Boden // Taguugber. Akad. Londwirtschaftwiss. DDR. - 1986. - N 245. - P. 57-62.

17. Krizhnazamy R. Influence of organic on vertizolz and inceptisolz / R. Krizhnazamy, K. K. Krizhnamoorthy // Ind. Soc. Sc. - 1991. - N 4. - P. 667-671.

18. Sorption kinetics and equilibria of organic pesticides in carbonatic soils from South Florida / P. Nkedi-Kizzaa, D. Shindea, M. R. Savabib, Y. Ouyangc, L. Nieves // J. Environ. Qual. - 2006. Vol. 35. - P. 268-276.

Надійшла до редколегї 10.10.2008 